1982, was controlled with metformin $500 \mathrm{mg}$ twice daily.

At laparotomy the duodenal nodule was resected and the liver appeared clear. Histology confirmed a non-argyrophilic, non-argentophilic, trabecular carcinoid tumour which had not invaded the muscularis propria. A urinary screen for 5 hydroxyindole acetic acid gave a negative result.

Although carcinoid tumours are the most common primary tumour of the small intestine, duodenal carcinoids are rare.' In the case of gastric carcinoids gastrin may play a part as it appears to act as a trophic hormone. ${ }^{2}$ The relation between drug induced hypergastrinaemia and carcinoids remains the subject of much debate. ${ }^{3}$ Carcinoid tumours found in patients with chronic atrophic gastritis or pernicious anaemia, ${ }^{+}$or in rats given long term $\mathrm{H}_{2}$ antagonists, appear to be confined to the gastric fundus. ${ }^{5}$ Nevertheless, the occurrence of such an unusual tumour in a patient receiving long term treatment with ranitidine leads us to suspect that the two may be interrelated. Neither the manufacturer nor the Committee on Safety of Medicines is aware of any previous reports of such an association

1 Barclay THC, Schapira DV. Malignant tumours of the smal intestine. Cancer 1983;51:878-81.

2 Hakanson R, Oscarson J, Sundler F. Gastrin and the trophic control of gastric mucosa. Scand F Gastroenterol 1986;21 (supp 118): 18-30.

3 Penston J, Wormsley KG. Achlorhydria: hypergastrinaemia arcinoids - a flawed hypothesis? (iut 1987;28:488-505.

4 Borch K, Renvall H, Liedberg G. Endocrine cell proliferation and carcinoid development: a review of new aspects of hypergastrinaemic atrophic gastritis. Digestion 1986;35(supp 1):106-15.

Sundler F, Carlsson E, Hakanson R, Larsson H, Mattsson H. Inhibition of gastric acid secretion by omeprazole and ranitidine. Effect on plasma gastrin and gastric histamine, histidin decarboxylase activity and ECL density in normal and antrectomized rats. Scand F Gastroenterol 1986;21(suppl 118):39-46.

\section{Sudden death after treatment with pulsed methylprednisolone}

Drs P V G GARDINER and I D GRIFFITHS (Drug and Therapeutics Unit, Queen Elizabeth Hospital, Birmingham B15 2TH) write: We wish to report a case of sudden death following intravenous methylprednisolone in a patient with rheumatoid arthritis. The interval between giving the drug and death was 10 days-certainly longer than in previous reports; the absence of any other known cause of death in this woman has prompted this report.

A 49 year old woman seropositive for rheumatoid arthritis was admitted for investigation of anaemia and treatment of active polyarthritis. There was no history of cardiac disease. She had been treated with penicillamine for two years and monitored appropriately. She had initially derived some benefit but later complained that the pain and stiffness were returning. A gradual fall in her haemoglobin concentration had occurred in the absence of dyspepsia or melaena. On examination she seemed anaemic, but no abnormalities were noted on abdominal or rectal examination. There was evidence of active rheumatoid arthritis. Results of cardiovascular examination were normal apart from a short systolic murmur heard at the left sternal edge. On admission her haemoglobin concentration was $76 \mathrm{~g} / \mathrm{l}$ (mean corpuscular volume $673 \mathrm{fl}$, mean corpuscular haemoglobin concentration 0.29 ); erythrocyte sedimentation rate was $92 \mathrm{~mm}$ in the first hour. Iron studies confirmed iron deficiency, and faecal occult blood tests were repeatedly negative. Electrolyte, urea and creatinine concentrations were within norma limits. Her chest $x$ ray film and electrocardiogram were normal. Endoscopy was normal apart from mild oesophagitis.

Management included bed rest, intra-articular steroid injections (total $50 \mathrm{mg}$ triamcinolone), and iron given orally. Two $500 \mathrm{mg}$ pulses of intravenous methylprednisolone were given, each over a period of one hour, 48 hours apart. The patient felt well during each infusion, and no change in her pulse rate was noted. Her mobility improved considerably, and three days later she was discharged.

Ten days after the last dose of methylprednisolone she died suddenly at home. Her husband reported that she had remained well up to 50 minutes before her death - the last time she had been seen alive- and had not complained of chest pain, shortness of breath, or palpitations.

Necropsy showed terminal pulmonary congestion and deformed joints but no other relevant abnormalities. In particular, careful examination of the coronary arteries showed only early atheromatous changes, and no infarcts or emboli were noted. Examination of the valves revealed no abnormality, and it was therefore assumed that the systolic murmur had been caused by her anaemia. No gastrointestinal or intracranial abnormality was found.

Several cases of sudden death after taking dexamethasone or methylprednisolone have been reported. ${ }^{1+}$ Some, but not all, were associated with rapid infusions or pre-existing heart disease. Studies in animals have suggested that intravenous steroids can be arrhythmogenic, and speed of administration has been suggested as an important factor. ${ }^{+}$In a prospective study Tvede et al carried out twice daily electrocardiography after giving $500 \mathrm{mg}$ methylprednisolone intravenously to five patients.' Bradycardia was documented in all patients (but was symptomatic in only one), and the pulse rate of all patients did not return to normal until the seventh day. A terminal arrhythmia has rarely been documented, but in the case reported by Moses et al junctional bradycardia was noted.

The fact that "silent" bradycardia can persist for at least six days after taking methylprednisolone suggests that we may be overlooking "late" deaths related to this treatment. Fatal events relating to pulsed methylprednisolone therapy are, however, undoubtedly rare and usually occur in patients with considerable coexisting disease. Our patient may well have developed an arrhythmia after treatment with methylprednisolone, but this could have been a coincidental event. It is possible that her anaemia was a relevant factor, rendering fatal an arrhythmia that might otherwise have been innocuous.

1 Schmidt GB, Meier MA, Sadove MS. Sudden appearance of cardiac arrhythmias after dexamethasone. FAMA 1972;221 $1402-4$

2 Bocanegra TS, Castaneda MO, Espinoza LR, Vasey FB, Germain BF. Sudden death after methylprednisolone pulse therapy. Ann Intern Med 1981;95:122.

3 Moses RE, McCormick A, Nickey W. Fatal arrhythmia after methylprednisolone therapy. Ann Intern Med 1981;95:781-2.

Barry $M$. The use of high dose pulse methylprednisolone in rheumatoid arthritis. Arch Intern Med 1985;145:1483-4.

5 Tvede N, Nielsen LP, Andersen V. Bradycardia after high-dose methylprednisolone therapy. Scand I Rheumatol 1986;15: methyl $302-4$.

\section{Laxative induced magnesium poisoning in a 6 week old infant}

Drs Lilias H Alison and D Bulugahapitiya (Rotherham District General Hospital, Rotherham S60 2UD) write: Hypermagnesaemia is a recognised complication of treatment with magnesium preparations but has rarely been reported in paediatric practice. We describe a baby who had life threatening apnoeas due to magnesium hydroxide used to treat constipation.

A 6 week old, previously healthy boy was admitted with apnoeic episodes. In the week before presentation he had become constipated and had been prescribed magnesium hydroxide mixture $550 \mathrm{mg} / 10 \mathrm{ml}$ (Milk of Magnesia) for 48 hours in doses of one third of a $5 \mathrm{ml}$ teaspoon with feeds, 16 doses being given in 48 hours. Twelve hours before presentation he became increasingly lethargic and then had numerous apnoeic episodes in the hour before admission. At presentation he was drowsy and had few spontaneous movements. Respiratory effort was poor and one further episode of apnoea was witnessed. His pupils were dilated and reacted sluggishly to light. He was hypotonic and areflexic. His pulse and blood pressure were normal. Electrocardiography confirmed sinus rhythm.

Biochemical investigations showed hypermagnesaemia with metabolic alkalosis: serum sodium concentration $136 \mathrm{mmol} / \mathrm{l}$; serum potassium 3.6 $\mathrm{mmol} / \mathrm{l}$; plasma urea $6.9 \mathrm{mmol} / \mathrm{l}$; plasma creatinine $44 \mu \mathrm{mol} / \mathrm{l}$; serum magnesium $5.85 \mathrm{mmol} / \mathrm{l}$; serum calcium $1.87 \mathrm{mmol} / \mathrm{l}$; and serum albumin $35 \mathrm{~g} / \mathrm{l}$; capillary blood $\mathrm{pH} 7.55$; carbon dioxide tension $6.3 \mathrm{kPa}$; base excess $+18 \mathrm{mmol} / \mathrm{l}$; and bicarbonate concentration $42 \mathrm{mmol} / \mathrm{l}$. Maintenance $(150 \mathrm{ml} / \mathrm{kg}$ ) day) intravenous $4 \%$ dextrose in $0.18 \%$ sodium chloride infusion was started with additional calcium gluconate $1 \cdot 125 \mathrm{mmol} / \mathrm{kg} /$ day for 24 hours. Spontaneous respiration was adequate and tracheal intubation was not required. Continuous electrocardiography was performed and gave normal findings. No further apnoeas occurred. Within 10 hours he was increasingly active with return of deep tendon reflexes. By 48 hours he was normal and was discharged the next day. Results of serial biochemical monitoring are shown in the table.

Magnesium and calcium concentrations and $\mathrm{pH}$ over 30 hours

\begin{tabular}{|c|c|c|c|c|c|c|}
\hline & \multirow{2}{*}{$\begin{array}{l}\text { Reference } \\
\text { ranges }\end{array}$} & \multicolumn{5}{|c|}{ Hours after admission } \\
\hline & & 0 & 10 & 15 & 20 & 30 \\
\hline $\begin{array}{l}\text { Serum magnesium } \\
(\mathrm{mmol} / \mathrm{l})\end{array}$ & $0 \cdot 62-1 \cdot 03$ & $5 \cdot 85$ & $3 \cdot 21$ & $2 \cdot 15$ & $1 \cdot 30$ & $1 \cdot 03$ \\
\hline $\begin{array}{l}\text { Serum calcium } \\
\quad(\mathrm{mmol} / \mathrm{l})\end{array}$ & $2 \cdot 20-2 \cdot 75$ & $1 \cdot 87$ & $2 \cdot 08$ & $2 \cdot 40$ & 2.31 & $2 \cdot 43$ \\
\hline $\mathrm{pH}$ & $7 \cdot 35-7 \cdot 42$ & 7.55 & $7 \cdot 42$ & - & 23 & $7 \cdot 35$ \\
\hline $\begin{array}{l}\text { Random urinary } \\
\text { magnesium } \\
(\mathrm{mmol} / \mathrm{l})\end{array}$ & $\begin{array}{c}\text { Not } \\
\text { known }\end{array}$ & 111 & 60 & - & - & 2 \\
\hline
\end{tabular}

* Paediatric data available only for 24 hour urinary magnesium excretion: range $0 \cdot 06-0 \cdot 15 \mathrm{mmol} / \mathrm{kg} / 24 \mathrm{~h}$.

Magnesium toxicity is well described in adults and is usually iatrogenic.' It rarely occurs in the absence of intestinal or renal disease. Hypermagnesaemia in children is rare. Neonatal hypermagnesaemia is a recognised complication of treating maternal pre-clampsia in labour with large doses of parenteral magnesium. ${ }^{2}$ It has also been reported in a neonate receiving tolazoline and given antacids containing magnesium to protect against gastrointestinal haemorrhage." Hypermagnesaemia causes neuromuscular dysfunction by inhibiting acetylcholine release at the neuromuscular junction. Values above $3 \mathrm{mmol} / \mathrm{l}$ produce loss of deep tendon reflexes, hypotonia, and progressive paralysis. Values of $5 \mathrm{mmol} / \mathrm{l}$ or more may cause respiratory arrest, heart block, and asystole.

Standard paediatric textbooks still recommend magnesium hydroxide in doses of one to two teaspoons for unresponsive or severe constipation in infancy. The manufacturers, however, have no recommended dosage to children under 1 year. This case shows the dangers of prescribing magnesium compounds to infants. Caution should be exercised in prescribing drugs "with feeds" in infancy, as their frequent feeding pattern may result in drug toxicity.

Mordes JP, Wacker WEC. Excess magnesium. Pharmacol Rev 1977;29:273-300.

2 Lipitz PJ. The clinical and biochemical effects of excess magnesium in the newborn. Paediatrics 1971;47:501-9.

3 Humprey M, Kennon S, Pramanki A. Hypermagnesemia from antacid administration in a newborn infant. $\mathcal{I}$ Pediatr 1981; 98:313-4.

4 Brenton DP, Gordon TE. Fluid and electrolyte disorders: magnesium. Brf Hosp Med 1984 Aug:60-9.

5 Behrman RE, Vaughan VC, eds. Nelson textbook of paediatrics.

13th ed. Philadelphia: W B Saunders, 1977:136. 